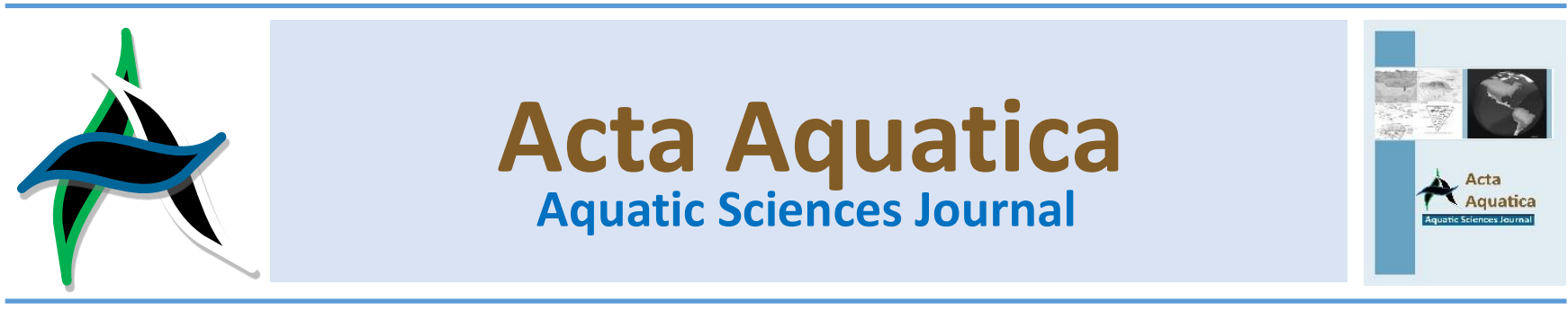

\title{
Pengaruh media filter pada sistem resirkulasi air untuk pemeliharaan ikan koi (Cyprinus carpio L)
}

\section{The effect of filter media on water recirculation system in raising goldfish (Cyprinus carpio L)}

\author{
Teuku Die Aulya Rizky ${ }^{\text {a }}$, Riri Ezraneti ${ }^{\text {a* }}$ dan Saiful Adhar ${ }^{\text {a }}$ \\ a Program Studi Budidaya Perairan, Fakultas Pertanian, Universitas Malikussaleh
}

\begin{abstract}
Abstrak
Penelitian ini dilakukan di Laboratorium Hatchery dan Teknologi Budidaya Program Studi Budidaya Perairan Fakultas Pertanian Universitas Malikussaleh, dimulai dari tanggal 10 Juni sampai dengan 9 Juni 2015. Ikan uji yang digunakan adalah benih ikan Koi yang berukuran $5-7 \mathrm{~cm}$. Tujuan penelitian ini adalah untuk mengetahu pengaruh media filter pada sistem resirkulasi air terhadap pemeliharaan ikan koi. Penelitian ini menggunakan metode eksperimental dengan Rancangan Acak Lengkap (RAL) non factorial dengan empat perlakuan dan tiga kali ulangan. Pertambahan panjang terbesar terdapat pada filter arang yaitu $0,47 \mathrm{~cm}$ dan terkecil pada filter kijing yaitu $0,36 \mathrm{~cm}$. Pertambahan berat terbesar terdapat pada filter kontrol yaitu 1,21 gram dan terkecil pada filter kijing yaitu 1 gram. Hasil penelitian menunjukkan bahwa media filter pada sistem resirkulasi air tidak berbeda nyata terhadap pertumbuhan, konversi pakan dan kelangsungan hidup ikan koi.
\end{abstract}

Kata kunci: Koi; Filter; Resirkulasi

\begin{abstract}
This study was carried out at Hatchery and Aquaculture Technology Laboratory, Aquaculture Department Agriculture Faculty Malikussaleh University started on June 10th to July 9th 2015. Experimented fish was goldfish fingerling which had length 5-7 cm.The purpose of this study was to know the effect of filter media on water recirculation system in raising goldfish. Experimental design used was non-factorial completely randomized design with four treatments and three replications. the highest length growth of goldfish was showed in charcoal filter which was $0,47 \mathrm{~cm}$ while the lowest one was in kijing filter which was $0,36 \mathrm{~cm}$. The highest weight growth of goldfish was obtained in control filter which was 1,21 grams and the lowest one was in clams (kijing) filter which was 1 gram. The result implied that filter media on water recirculation system did not give significant different on growth, food convertion ratio, and survival rate of gold fish.
\end{abstract}

\section{Pendahuluan}

Ikan koi merupakan ikan hias favorit dan banyak digemari oleh masyarakat luas di Indonesia. Ikan koi sampai saat ini masih menjadi salah satu komoditas bernilai tinggi dalam bidang perikanan. Apabila dipelihara dalam skala besar dapat digunakan sebagai mata pencaharian sekaligus dapat menciptakan lapangan pekerjaan baru. Ikan koi juga dapat dipelihara di dalam akuarium sebagai penyaluran hobi dengan mengamati keindahan geraknya.

Pengembangan industri akuakultur untuk meningkatkan produksi dibatasi oleh beberapa faktor yaitu keterbatasan air, lahan dan polusi terhadap lingkungan. Air sebagai media pemeliharan ikan harus selalu diperhatikan kualitasnya.

\footnotetext{
* Korespondensi: Prodi Budidaya Perairan, Fakultas Pertanian, Universitas Malikussaleh. Kampus utama Reuleut,

Kabupaten Aceh Utara, Aceh, Indonesia.

Tel: +62-645-41373 Fax: +62-645-59089.

e-mail: ririezra@yahoo.com
}

Intensifikasi budidaya melalui padat tebar dan laju pemberian pakan yang tinggi dapat menimbulkan masalah kualitas air. Walaupun ikan memakan sebagian besar pakan yang diberikan tetapi persentase terbesar diekskresikan menjadi buangan metabolik (nitrogen). Usaha yang dapat dilakukan untuk menanggulangi permasalahan di atas adalah mengaplikasikan sistem resirkulasi akuakultur. Sistem resirkulasi pada prinsipnya adalah penggunaan kembali air yang telah dikeluarkan dari kegiatan budidaya. Fokus utama pada sistem resirkulasi adalah pemindahan amonia sebagai zat hasil proses metabolisme ikan. Sistem resirkulasi dapat dilakukan dengan menggunakan media filter yang berbeda berupa arang, kijing dan tumbuhan paku.

Penelitian ini memiliki tujuan untuk mengetahui pengaruh media filter pada sistem resirkulasi air terhadap pertumbuhan, konversi pakan dan kelangsungan hidup ikan koi dan mengetahui media filter mana yang terbaik pada sistem resirkulasi air untuk pertumbuhan ikan koi. Diharapkan hasil penelitian ini dapat menjadi informasi yang dapat digunakan sebagai referensi dalam penelitian ikan koi. 


\section{Bahan dan metode}

\subsection{Waktu dan tempat}

Penelitian ini dilaksanakan pada bulan Juni - Juli 2015 yang bertempat di Laboratorium Hatchery dan Teknologi Budidaya Program Studi Budidaya Perairan Fakultas Pertanian Universitas Malikussaleh.

\subsection{Bahan dan alat}

Penelitian ini menggunakan sistem resirkulasi dengan menempatkan media filter terpisah dari wadah pemeliharaan ikan yaitu akuarium dengan ukuran $60 \times 40 \times 30 \mathrm{~cm}^{3}$ dan diisi air sebanyak $30 \mathrm{~L}$, wadah filter berupa ember dengan volume 30 liter air dengan menggunakan pompa berkekuatan $50 \mathrm{~L} /$ menit.

\subsection{Metode dan rancangan penelitian}

Metode penelitian dilakukan secara eksperimental dengan menggunakan Rancangan Acak Lengkap (RAL) non faktorial 4 perlakuan 3 kali ulangan. Filter yang digunakan saat penelitian masing - masing sebanyak 600 gram. Parameterparameter yang diamati adalah kualitas air berupa $\mathrm{pH}$, suhu amonia, pertumbuhan, konversi pakan dan kelangsungan hidup ikan koi.

Penelitian pendahuluan dilakukan untuk pengkondisian sistem. Jumlah ikan yang digunakan setiap perlakuan adalah 30 ekor, pemberian pakan diberikan dua kali/hari. Pakan yang diberikan pada ikan diberi secara at-satiation atau sekenyangnya. Data pertumbuhan, konversi pakan dan kelangsungan hidup ikan koi akan dianalisis menggunakan uji sidik ragam menggunakan aplikasi SPSS dan disajikan dalam bentuk tabel dan grafik serta dilakukan pembahasan secara deskriptif.

\section{Hasil dan pembahasan}

\subsection{Kualitas air media}

Parameter kualitas air yang diamati selama penelitian dapat dilihat pada Tabel 1.

Tabel 1. Kisaran parameter kualitas air media pemeliharaan dan hasill pengukuran pada saat penelitian.

\begin{tabular}{ccccc}
\hline Perlakuan & Kontrol & Arang & Kijing & Azolla \\
\hline $\mathrm{pH}$ & $7,1-8,1$ & $7,1-8,2$ & $7,0-8,2$ & $7,1-8,5$ \\
Suhu & $28,1-31,1$ & $28,0-30,4$ & $28,1-30,1$ & $28,0-30,8$ \\
Amonia & $0,03-3,34$ & $0,03-2,82$ & $0,08-3,28$ & $0,03-0,17$ \\
\hline
\end{tabular}

Derajat keasaman $(\mathrm{pH})$ juga menentukan bagi pertumbuhan ikan. Nilai keasaman air menunjukkan kisaran yang berbeda dari setiap perlakuan. Pada filter kontrol 7,1-8,1, filter arang 7,1-8,2, filter kijing 7,0-7,9 dan filter azolla 7,1 8,5. Derajat keasaman $(\mathrm{pH})$ menunjukkan keadaan air pada kondisi asam atau basa. Dari tabel 8 diatas menunjukkan $\mathrm{pH}$ pada media pemeliharaan ikan koi berada pada kisaran yang baik. Hal ini sesuai dengan pendapat Perkasa dan Hikmat (2001) yang menyatakan bahwa kisaran $\mathrm{pH}$ yang baik untuk pemeliharaan ikan koi yaitu 6,5 - 8,5.

Suhu air merupakan salah satu faktor yang mempengaruhi nafsu makan dan pertumbuhan ikan, metabolisme ikan serta mempengaruhi kadar oksigen yang terlarut dalam air. Berdasarkan hasil pengukuran kualitas air bahwa suhu air cenderung stabil dan tidak menunjukkan adanya kenaikan dan penurunan secara drastis dan tetap pada kisaran yang baik untuk pemeliharaan benih ikan koi. Pada filter Kontrol $28,1^{\circ}-31,1^{\circ} \mathrm{C}$, filter arang $28,0^{\circ}-30,4^{\circ} \mathrm{C}$, filter kijing $28^{\circ}-30,1^{\circ} \mathrm{C}$ dan filter Azolla $28^{\circ}-31,1^{\circ} \mathrm{C}$. Hal ini sesuai dengan pendapat Khairuman dan Amri, 2000) bahwa ikan koi dapat hidup pada suhu yang berkisar antara $25^{\circ}-30^{\circ} \mathrm{C}$.

Amonia adalah senyawa nitrogen dan hidrogen yang memiliki aroma tajam dengan bau yang khas. Sebuah molekul amonia terbentuk dari ion nitrogen bermuatan negatif dan tiga ion hidrogen bermuatan positif, dan karena itu secara kimia direpresentasikan sebagai $\mathrm{NH}_{3}$. Amonia dapat terjadi secara alami atau dapat diproduksi (Silaban et al., 2012). Berdasarkan hasil penelitian yang dilakukan selama 28 hari, dapat dilihat parameter amonia selama empat minggu menunjukkan hasil yang berbeda pada masing-masing perlakuan. Rata-rata parameter amonia pada tiap perlakuan dapat dilihat pada Gambar 1.

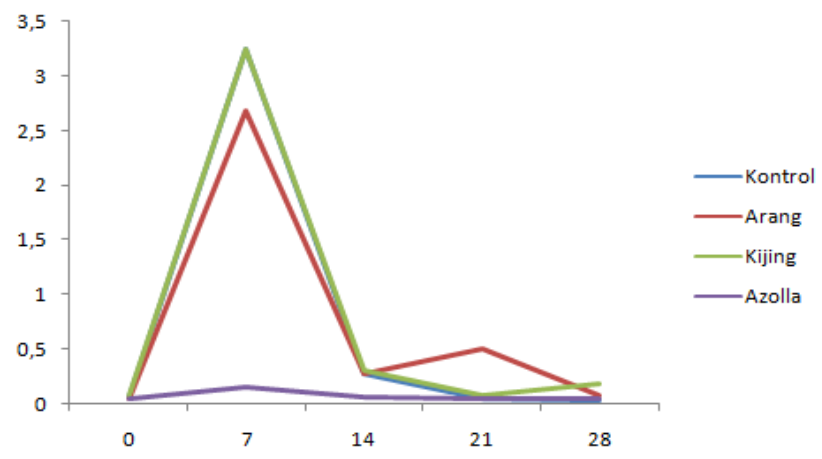

Gambar 1. Grafik peningkatan amonia pada tiap perlakuan.

Berdasarkan grafik di atas parameter amonia meningkat pada hari ke 7. Peningkatan amonia terbesar pada hari ke 7 terdapat pada filter arang, kontrol dan kijing, sedangkan pada filter azolla peningkatan amonianya tidak terlalu tinggi. Pada hari ke 14 seluruh parameter amonia pada masing-masing perlakuan menjadi lebih rendah. Pada hari ke 21 juga demikian, tetapi pada filter arang meningkat sedikit. Pada hari ke 28 parameter amonia dari seluruh perlakuan kembali menjadi rendah.

\subsection{Pertambahan panjang}

Hasil penelitian menunjukkan bahwa media filter pada sistem resirkulasi air memiliki hasil yang berbeda terhadap pertambahan panjang ikan koi. Rata-rata pertambahan panjang ikan koi untuk masing-masing perlakuan dapat dilihat pada Tabel 2.

Tabel 2. Pertambahan panjang benih ikan koi (Cyprinus carpio L).

\begin{tabular}{cc}
\hline Media filter & Rata-rata pertambahan panjang $(\mathrm{cm})$ \\
\hline Kontrol & 0,45 \\
Arang & 0,47 \\
Kijing & 0,36 \\
Azolla & 0,44 \\
\hline
\end{tabular}

Berdasarkan Tabel 2 diatas dapat dilihat bahwa rata-rata pertambahan panjang tertinggi terdapat pada filter arang sebesar 0,47 cm, disusul filter kontrol 0,45 cm, filter azolla 0,44 $\mathrm{cm}$ dan pertambahan panjang terendah pada filter kijing sebesar $0,36 \mathrm{~cm}$. Kondisi pertambahan panjang pada kontrol tidak sejalan dengan pertambahan beratnya. Menurut Dewiyanti, et al., (2012) bahwasanya kondisi panjang dan berat ikan tidak selamanya sejalan. Kondisi ini disebut dengan allometrik. Hal ini terjadi karena pengaruh reaksi gen, keturunan, sex, umur, parasit dan penyakit pada tubuh ikan. 
Hasil analisa Anova menunjukkan bahwa media filter tidak berpengaruh nyata terhadap pertumbuhan panjang ikan koi dengan nilai $F_{\text {hitung }}(0,562)<F_{\text {tabel }} 0.05(4,07)$. Pada filter arang terdapat pertambahan panjang yang terbaik, hal ini diduga karena pada arang mengandung karbon yang dapat menyerap amonia, proses filterisasi yang menjadi lebih optimal sehingga dapat menambah nafsu makan ikan dan proses metabolismenya tidak terganggu sehingga pertumbahan panjang ikan menjadi baik. Penggunaan filter berguna sebagai filterisasi bagi air yang digunakan untuk budidaya. Nilai kualitas air dipengaruhi oleh media filter. Selanjutnya air dengan sistem resirkulasi lebih terjaga kualitasnya (Lasordo, 1998). Hal ini didukung oleh penelitian Mulyadi et al. (2013) yang menyatakan bahwa media filter pada sistem resirkulasi tidak berpengaruh nyata pada pertambahan panjang ikan koi.

\subsection{Pertambahan berat}

Berdasarkan hasil penelitian menunjukkan bahwa ratarata pertambahan berat berbeda. Rata-rata pertambahan berat ikan koi untuk masing-masing perlakuan dapat dilihat pada Tabel 3. Rata-rata pertambahan berat tertinggi terdapat pada filter kontrol sebesar 1,21 gr, disusul filter Azolla 1,18 gr, filter arang 1,10 gr dan pertambahan berat terendah pada filter kijing sebesar 1,00 gr. Pertumbuhan yang ditandai dengan meningkatnya berat dan panjang tubuh ikan menunjukkan bahwa pemberian pakan yang diberi selama penelitian mampu meningkatkan pertumbuhan. Hasil analisis Anova menunjukkan bahwa media filter tidak berpengaruh nyata terhadap pertumbuhan berat ikan koi $F_{\text {hitung }}(0,351)<F_{\text {tabel }} 0.05(4,07)$. Pertambahan berat paling besar terdapat pada filter kontrol, hal ini dapat disimpulkan bahwa dengan adanya media filter, hasil pertambahan beratnya sama dengan tidak adanya media filter.

Tabel 3. Pertambahan berat benih ikan koi (Cyprinus carpio L).

\begin{tabular}{cc}
\hline Media filter & Rata-rata pertambahan berat $(\mathrm{gr})$ \\
\hline Kontrol & 1,21 \\
Arang & 1,1 \\
Kijing & 1 \\
Azolla & 1,18 \\
\hline
\end{tabular}

\subsection{Konversi pakan}

Berdasarkan hasil penelitian menunjukkan bahwa media filter pada sistem resirkulasi air menunjukkan hasil yang berbeda terhadap konversi pakan benih ikan koi (Gambar 2).

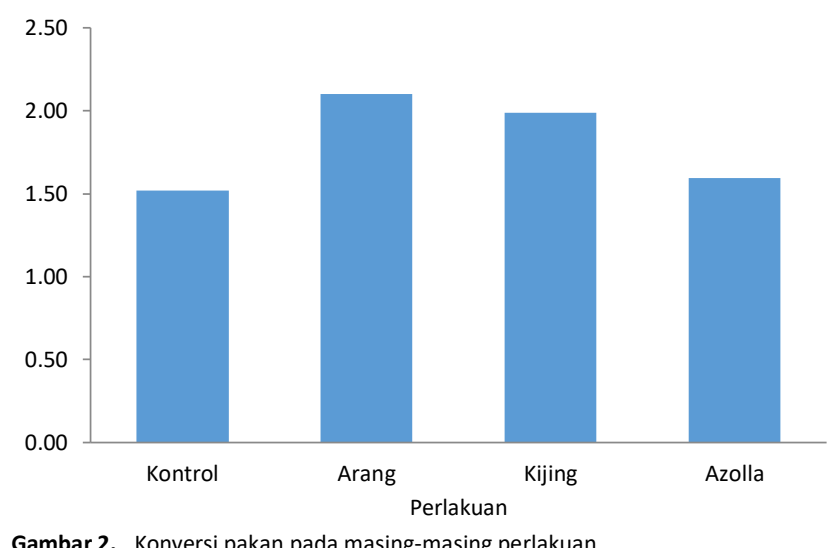

Rata-rata konversi pakan tertinggi terdapat pada filter arang sebesar 2,10 gr, disusul filter kijing 1,99 gr, filter azolla 1,60 gr dan konversi pakan terendah pada filter kontrol sebesar 1,52 gr.
Hasil analisis Anova menunjukkan bahwa media filter tidak berpengaruh nyata terhadap konversi pakan ikan koi $F_{\text {hitung }}$ $(0,142)<F_{\text {tabel }} 0.05(4,07)$. Hal ini menunjukkan bahwa ikan dapat memanfaatkan pakan yang diberikan dengan baik sehingga pakan tersebut terserap dan berubah menjadi daging. Hal ini sesuai dengan pernyataan Mudjiman (2001), bahwa nilai rasio konversi pakan berhubungan erat dengan kualitas pakan, sehingga semakin rendah nilainya maka semakin baik kualitas pakan dan makin efisien ikan dalam memanfaatkan pakan yang dikonsumsinya untuk pertumbuhan. Sehingga bobot tubuh ikan dapat meningkat dikarenakan pakan dapat dicerna secara optimal. Hal ini didukung oleh penelitian Putra et al. (2011) yang menyatakan bahwa media filter pada sistem resirkulasi tidak berpengaruh nyata pada konversi pakan ikan koi.

\subsection{Kelangsungan hidup}

Berdasarkan hasil penelitian yang dilakukan selama 28 hari, dapat dilihat tingkat kelangsungan hidup benih ikan koi selama empat minggu menunjukkan hasil yang berbeda pada masing-masing perlakuan. Rata-rata kelangsungan hidup benih ikan koi dapat dilihat pada Gambar 3.

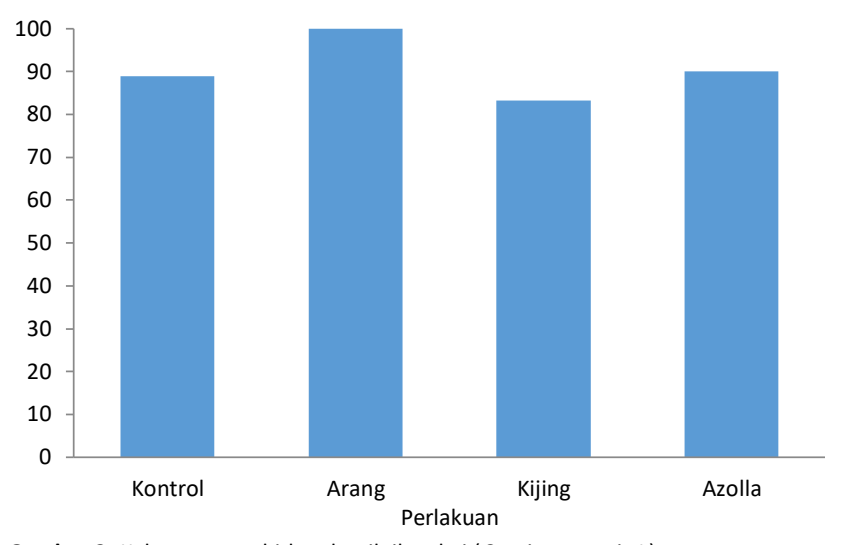

Gambar 3. Kelangsungan hidup benih ikan koi (Cyprinus carpio L)

Rata-rata kelangsungan hidup tertinggi terdapat pada filter arang sebesar $100 \%$, disusul filter azolla sebesar 89,99\%, hal ini disebabkan pada saat penelitian azollanya mati, sehingga warna air menjadi keruh yang menjadikan ikan stres sehingga menyebabkan kematian. Kematian azolla disebabkan kurangnya sinar matahari, sehingga azolla tidak dapat melakukan fotosintesis (Dewi, 2007).

Pada filter kontrol kelangsungan hidupnya 88,89\%, kelangsungan hidup terendah pada perlakuan kontrol disebabkan kualitas air yang menurun karena tidak ada filter. Hal ini menyebabkan air menjadi keruh dan parameter amonia meningkat akibat adanya penumpukan feses. Kelangsungan hidup terendah terdapat pada filter kijing, yaitu sebesar 83,33\%. $\mathrm{Hal}$ ini disebabkan pada saat penelitian ada beberapa ekor kijing yang mati sehingga dapat memperburuk kualitas air. Kematian kijing diduga karena penempatan kijing di dalam wadah tidak sesuai dengan habitatnya yang tidak ada lumpur dan juga batu tempat kijing melekat (Sugiri, 1989).

Hasil analisis Anova menunjukkan bahwa media filter tidak berpengaruh nyata terhadap kelangsungan hidup ikan koi $F_{\text {hitung }}(1,099)<F_{\text {tabel }} 0.05(4,07)$. Terbukti bahwa Persentase kelulushidupan adalah perbandingan jumlah ikan uji yang hidup pada akhir penelitian dengan awal penelitian pada satu periode dalam satu populasi. Hal ini disebabkan bahwa pada filter arang terjadinya proses filterisasi yang optimal sehingga menghasilkan kualitas air yang bagus di dalam media pemeliharaan ikan koi. Hal ini didukung oleh penelitian Nugroho et al. (2013) yang menyatakan bahwa media filter pada sistem resirkulasi 
menggunakan filter arang tidak berpengaruh nyata pada kelangsungan hidup ikan koi.

Sistem resirkulasi dapat memperbaiki kualitas air di dalam media pemeliharaan yang sangat berpengaruh bagi kehidupan ikan koi. Selain kualitas air ada faktor lain yang menunjang kelulushidupan seperti pemberian pakan yang cukup. Ikan koi termasuk ikan yang mudah beradaptasi dengan lingkungan. Kematian ikan dapat terjadi disebabkan oleh predator, parasit, penyakit, populasi, keadaan lingkungan yang tidak cocok serta fisik yang disebabkan oleh penanganan manusia. Selanjutnya faktor yang mempengaruhi tinggi rendahnya kelangsungan hidup adalah faktor abiotik dan biotik, antara lain: kompetitor, kepadatan populasi, umur dan kemampuan organisme beradaptasi dengan lingkungan (Effendi, 1979).

\section{Kesimpulan}

Berdasarkan hasil penelitian dapat disimpulkan bahwa pertambahan panjang tidak sejalan dengan pertambahan berat pada ikan koi yang disebut dengan istilah allometrik. Penggunaan media filter baik berupa arang, kijing dan azola tidak berpengaruh nyata pada pertumbuhan, konversi pakan dan kelangsungan hidup ikan koi.

\section{Bibliografi}

Dewi, A. I. R., 2007. Fiksasi N Biologis Pada Ekosistem Tropis. Program Pasca Sarjana Universitas Padjadjaran Bandung. HIm 37-38.

Dewiyanti, I., 2012. Hubungan Panjang Berat Dan Faktor Kondisi Tiga Jenis Ikan Yang Tertangkap Di Perairan Kuala Gigieng, Aceh Besar, Provinsi Aceh. Universitas Syiah Kuala. 1(1):1-9

Effendie, M. I., 1979. Metode Biologi Perikanan. Gramedia Pustaka Utama, Jakarta.

Hikmat, 2001. Strategi Pemberdayaan Masyarakat. Bandung. Humaniora UtamaPress (HUP).

Khairuman dan Amri, 2000. Budidaya Ikan Mas Secara Intensif. Agromedia Pustaka.Subang.

Mujiman, A., 2001. Makanan Ikan. Penebar Swadaya. Jakarta.

Lasordo, M., 1998. Resirculating Aquaculture Production System: The Status and Future. Aquaculture Magazine. 24 (1): 38 45.

Mulyadi, A. E., 2011. Pengaruh Pemberian Probiotik Pada Pakan Komersil Terhadap Laju Pertumbuhan Benih Ikan Patin Siam (Pangasisus hypothaimus). Skripsi Fakultas Perikanan dan IImu Kelautan Unpad. Jatinangor Tidak Dipublikasikan.

Mulyadi, 2013. Sistem Resirkulasi Dengan Menggunakan Filter Yang Berbeda Terhadap Pertumbuhan Benih Ikan Nila (Oreochromis Niloticus). Jurnal Akuakultur Rawa Indonesia, 2(2): 117-124.

Nugroho, 2013. Pengaruh Kepadatan Yang Berbeda Terhadap Kelulushidupan dan Pertumbuhan Ikan Nila
(Oreochromis Niloticus) Pada Sistem Resirkulasi Dengan Filter Arang. Jurnal Aquaculture. 2 (1) : 94-100.

Putra, 2011. Pertumbuhan dan Kelangsungan Hidup Ikan Nila Pada Sistem Resirkulasi (Oreochromis Niloticus). Jurnal Perikanan dan Kelautan Vol.16 (1) (2011) : 56-63

Silaban, 2012. Dalam Peningkatan Kinerja Filter Air Untuk Menurunkan Konsentrasi Amonia Pada Pemeliharaan Ikan Mas (Cyprinus carpio). E-Jurnal Rekayasa dan Teknologi Budidaya Perairan. Vol. 1 (1): 47-56.

Suantika G., 2001. Development of A Recirculation System for The Mass Culturing of the Rotifer Brachionus plicatilis. Thesis Doktoral Universiteit Gent. Belgium.

Sugiri, N., 1989. Zoologi Invertebrata I/ Direktorat Pendidikan Tinggi. PAU-IImu Hayat Bogor. 